\title{
In-vitro binding of prostaglandin F-2 $\alpha$ to uterine luminal proteins of pregnant and non-pregnant ewes
}

\author{
W. F. Pope and F. Stormshak \\ Department of Animal Science, Oregon State University, Corvallis, Oregon 97331, U.S.A.
}

\begin{abstract}
Summary. Pregnant and non-pregnant ewes were utilized to determine whether the presence of the embryo affected the binding of prostaglandin (PG) F-2 $\alpha$ to a uterine luminal protein. The uterine horn adjacent to the corpus luteum was flushed on Day 13 of gestation or the oestrous cycle. Flushings were incubated with $\left[{ }^{3} \mathrm{H}\right] \mathrm{PGF}-2 \alpha$ and subsequently eluted through a Sephadex column. Uterine luminal proteins of pregnant and non-pregnant ewes eluted with the void volume and failed to bind PGF-2 $\alpha$.
\end{abstract}

\section{Introduction}

Moor \& Rowson (1966) observed a critical time, 12 and 13 days after mating, during which the ovine embryo must be present in the uterine lumen to offset the luteolytic activity of the uterus. McCracken, Baird \& Goding (1971) and Barrett et al. (1971) first proposed that prostaglandin (PG) F-2 $\alpha$ was the luteolytic agent liberated from the ovine uterus. Subsequently, many embryonic-induced modulations of PGF- $2 \alpha$ activity have been proposed. Thorburn, Cox, Currie, Restall \& Schneider (1973) and Barcikowski, Carlson, Wilson \& McCracken (1974) postulated that the presence of the embryo inhibited the release of PGF-2 $\alpha$ while Nett, McClellan \& Niswender (1976) reported that the presence of the embryo may reduce the frequency of PGF-2 $\alpha$ release. It has been proposed that maintenance of luteal function in the pregnant gilt is due to an alteration in the direction of secretion of PGF-2 $\alpha$ away from the vasculature towards the uterine lumen where it is sequestered (Bazer, Roberts \& Thatcher, 1977). If secretion of PGF-2 $\alpha$ is into the uterine lumen of the pregnant ewe, the conceptus either directly or indirectly may alter the biological effectiveness of PGF-2a, perhaps through the synthesis of a protein capable of binding to it and rendering this compound inactive. It is presumed that such a phenomenon would not necessarily preclude release of the proteinPGF- $2 \alpha$ complex into the uterine venous system.

The present experiment was conducted to determine whether uterine luminal proteins of ewes on Day 13 of gestation or the oestrous cycle differ in their ability to bind PGF-2 $\alpha$.

\section{Materials and Methods}

Ten mature crossbred ewes exhibiting oestrous cycles of normal duration were assigned randomly to two groups; one group to be mated and the other to remain non-pregnant. Five of these ewes were mated with an intact ram on the first day of oestrus (Day 0 ), which was detected by using vasectomized rams. Ewes were killed 13 days after mating or oestrus. The uterine horn adjacent to the ovary bearing the corpus luteum (CL) was occluded at the utero-tubal junction and anterior to the cervix with haemostats and placed on ice. In bilaterally ovulating ewes, one horn 
was chosen at random to be occluded. Pregnancy was verified by recovery of the conceptus and, in the event of a bilateral pregnancy, one horn was chosen at random. At the laboratory the isolated horn was flushed with $1 \mathrm{ml}$ saline $(9 \mathrm{~g} \mathrm{NaCl} / \mathrm{l})$ at $4^{\circ} \mathrm{C}$ and the flushing was centrifuged at $20000 \mathrm{~g}$ for $10 \mathrm{~min}$. The resulting supernatant was standardized to a $1 \mathrm{ml}$ volume with saline $\left(4^{\circ} \mathrm{C}\right)$. The horn was flushed with a volume of $1 \mathrm{ml}$ saline to preclude tissue damage due to distension and excessive dilution of the luminal proteins. A $100 \mu$ aliquot of the standardized flushing was incubated with $4.5 \mathrm{nM}\left[{ }^{3} \mathrm{H}\right]$ prostaglandin $\mathrm{F}-2 \alpha$ (sp. act. $10.9 \mathrm{Ci} / \mathrm{mmol}$ : New England Nuclear, Boston, Massachusetts) for $10 \mathrm{~min}$ at $39^{\circ} \mathrm{C}$ under nitrogen gas. The incubate was subsequently cooled on ice and eluted through a Sephadex G-15 column $(9 \mathrm{~mm} \times 30 \mathrm{~cm}$, $4^{\circ} \mathrm{C}$ ) buffered with $0.02 \mathrm{M}$-sodium phosphate-citrate $(\mathrm{pH} 7.4)$ with $0.02 \%(\mathrm{w} / \mathrm{v})$ sodium azide and $1 \mathrm{~mm}$-mercaptoethanol. The void volume of the column was $7 \mathrm{ml}$. Each column fraction (1 $\mathrm{ml}$ ) was analysed for $\left[{ }^{3} \mathrm{H}\right]$ PGF- $2 \alpha$ by counting a $0.5 \mathrm{ml}$ aliquot in $10 \mathrm{ml}$ scintillation fluid $(0.7 \%$ 2,5-diphenyloxazole in toluene : Triton X-100, 2:1 v/v). Additionally, column fractions of uterine flushings from 3 pregnant and 3 non-pregnant ewes were frozen and later analysed for protein concentration according to the method of Lowry, Rosebrough, Farr \& Randall (1951). Preliminary investigation demonstrated that free $\left[{ }^{3} \mathrm{H}\right]$ PGF- $2 \alpha$ eluted with $14 \mathrm{ml}$ buffer.

\section{Results and Discussion}

It did not appear from the results of this experiment that uterine luminal proteins of ewes on Day 13 of gestation or the cycle possess an affinity for PGF-2 $\alpha$. Uterine proteins of ewes, regardless of reproductive state, eluted with the void volume of the Sephadex G-15 column and failed to bind labelled PGF-2 $\alpha$ (Text-fig. 1). Uterine flushings of ewes on Day 13 of gestation have been reported to contain significantly greater concentrations of proteins and PGF-2 $\alpha$ than uterine flushings of ewes on Day 13 of the cycle (Ellinwood, Nett \& Niswender, 1979). However, the ratio of protein to PGF-2 $\alpha$ concentration in uterine flushings of pregnant or non-pregnant ewes in this latter study was in excess of 100000 to 1 . It is doubtful, therefore, that endogenous prostaglandins interfered with the binding of labelled PGF- $2 \alpha$ to uterine proteins in the present study. These data suggest that binding of PGF- $2 \alpha$ to uterine luminal proteins is not a

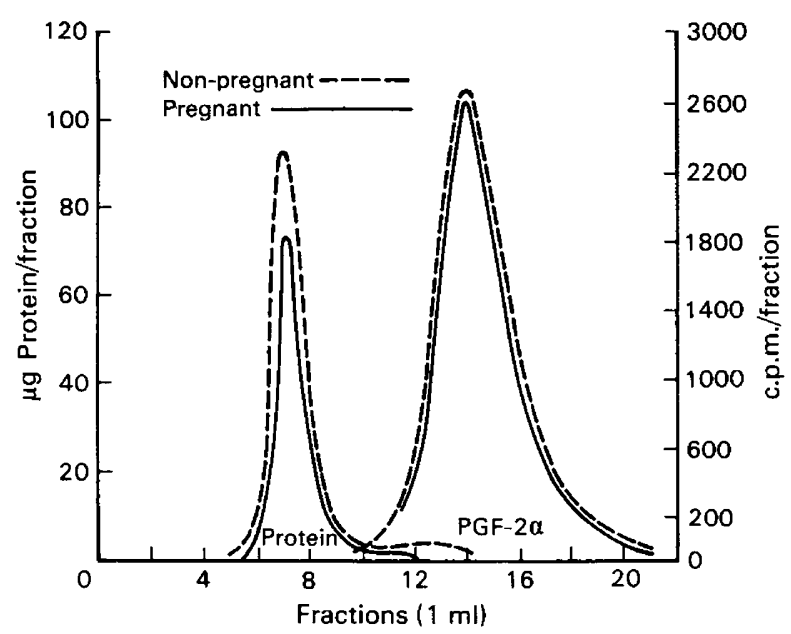

Text-fig. 1. Elution patterns of protein and $\left[{ }^{3} \mathrm{H}\right] \mathrm{PGF}-2 \alpha$ from uterine flushings of pregnant and non-pregnant ewes on Day 13 of gestation and the oestrous cycle, respectively. Concentrations of protein represent the mean for 3 pregnant and 3 non-pregnant ewes. Concentrations of $\left[{ }^{3} \mathrm{H}\right]$ PGF- $2 \alpha$ represent the mean for 5 pregnant and 5 non-pregnant ewes. 
contributory factor to luteal maintenance in the pregnant ewe. This premise is supported in part by the observations that concentrations of PGF-2 $\alpha$ in utero-ovarian venous blood of ewes on Days 13 and 15 of gestation are greater than or similar to those of ewes on comparable days of the cycle (Ellinwood et al., 1979; Pexton, Weems \& Inskeep, 1975).

Technical Paper No. 5260, Oregon Agricultural Experiment Station.

\section{References}

Barcikowski, B., Carison, J.C., Wilson, L. \& MeCracken, J.A. (1974) The effect of endogenous and exogenous estradiol-17 $\beta$ on the release of prostaglandin $F_{2} \alpha$ from the ovine uterus. Endocrinology 95, 1340-1349.

Barrett, S., de B. Blockey, M.A., Brown, J.M., Cumming, I.A., Goding, J.R., Mole, B.J. \& Obst, J.M. (1971) Initiation of the oestrous cycle in the ewe by infusions of PGF $a$ to the autotransplanted ovary. $J$. Reprod. Fert. 24, 136-137.

Bazer, F.W., Roberts, R.M. \& Thatcher, W.W. (1977) Actions of hormones on the uterus and effect on conceptus development. J. Anim. Sci. 49 (Suppl. 2), $35-45$.

Ellinwood, W.E., Nett, T.M. \& Niswender, G.D. (1979) Maintenance of the corpus luteum of early pregnancy in the ewe. II. Prostaglandin secretion by the endometrium in vitro and in vivo. Biol. Reprod. 21, 845-856.

Lowry, O.H., Rosebrough, N.J., Farr, A.L. \& Randall, R.J. (1951) Protein measurement with the folin phenol reagent. J. biol. Chem. 193, 265-275.
McCracken, J.A., Baird, D.T. \& Goding, J.R. (1971) Factors affecting the secretion of steroids from the transplanted ovary in sheep. Recent Prog. Horm. Res. 27, 537-582.

Moor, R.M. \& Rowson, L.E.A. (1966) The corpus luteum of the sheep: functional relationship between the embryo and the corpus luteum. J. Endocr. 34, 233-239.

Neth, T.M., MeClellan, M.C. \& Niswender, G.D. (1976) Effects of prostaglandins on the ovine corpus luteum: blood flow, secretion of progesterone and morphology. Biol. Reprod. 15, 66-78.

Pexton, J.E., Weems, C.W. \& Inskeep, E.K. (I975) Prostaglandins $F$ in uterine venous plasma, ovarian arterial and venous plasma and in ovarian and luteal tissue of pregnant and nonpregnant ewes. J. Anim. Sci. 41, 154-159.

Thorburn, G.D., Cox, R.I., Currie, W.B., Restall, B.J. Schneider, W. (1973) Prostaglandin F and progesterone concentrations in the utero-ovarian venous plasma of the ewe during the oestrous cycle and early pregnancy. J. Reprod. Fert., Suppl. 18, 151-158.

Received 14 January 1981 